\title{
THE EFFECT OF BIOMECHANICAL VARIABLES ON THE ASSESSMENT OF VAULTING IN TOP-LEVEL ARTISTIC FEMALE GYMNASTS IN WORLD CUP COMPETITIONS
}

\author{
Roman Farana, František Vaverka
}

Pedagogical Faculty, University of Ostrava, Ostrava, Czech Republic

Submitted in December, 2011

BACKGROUND: A vaulting performance takes a short time and it is influenced by and affects the quantity of mechanical variables. After the 2000 Olympic Games, the traditional horse was replaced by a new vaulting table. While the biomechanical data of vaulting using the new table (post 2000 Olympic competition) are not available yet, there is a question what the current technique of handspring performed by top-level female gymnasts looks like.

OBJECTIVE: The aim of the study is to determine the biomechanical factors that govern success in the performance of the handspring and front somersault vaults.

METHODS: Eight top-level female gymnasts participated in this study. For the 3D spatial movement analysis, two digital camcorders with a frame rate of 50 fields per second were used. The data was digitized by the Simi motion software. The method of Hay and Reid (1988) was used to identify the biomechanical variables that determine the linear and angular motions of the handspring and front somersault vaults. A correlation analysis was used to establish the strength of the relationship between the causal biomechanical variables and the judges' scores. The level of statistical significance was determined at the value of $\mathrm{p}<0.05$.

RESULTS: Five out of 23 examined variables showed significant correlations with the scores. A significant correlation was found in the vertical height of the body center of mass during the take-off from the vaulting table $(r=0.86)$, in the maximum height of the body center of mass in the second flight phase (0.83), in the change of the horizontal velocity during the phase of the take-off from the vaulting table $(r=-0.69)$, in the horizontal component of the velocity during the spring from the vaulting table $(\mathrm{r}=0.75)$ and in the duration of the second flight phase $(\mathrm{r}=0.69)$.

CONCLUSIONS: The phase of the take-off from the vaulting table is a crucial phase of the vault. Top-level artistic female gymnasts are able to execute the take-off from the vaulting table in a relatively short period of time with a full extent of the movement (maximization of the height of the body center of mass at the board take-off). The take-off from the vaulting table is executed at a high vertical and horizontal velocity that ensures a sufficient height of the vault and landing distance of from the vaulting table. The longer time of the second flight allowed gymnasts to complete the rotation motion during the second flight phase and perform a controlled and safe landing.

Keywords: Sports biomechanics, kinematics analysis, technique, correlation analysis, judge's score.

\section{INTRODUCTION}

The aim of artistic gymnastics is to find an optimal way of the motion action to achieve the best sport performance. Each sport performance has its own specific structure of factors that create the performance (Dovalil, 2005). The technical requirements and the difficulties of the single skills and the entire routines in artistic gymnastics have increased dramatically in the last thirty years (Brüggemann, 2005). The technique is one of the most important factors in gymnastics performance. Sport biomechanics can improve sport technique and training and minimize injuries (McGinnis, 2005).

Vaulting is the only apparatus involving a single movement and, for this reason, vaulting is the most researched and best understood apparatus (Prassas, Kwon, \& Sands, 2006). A vaulting performance takes a short time and it is influenced by and affects the quantity of mechanical variables. Each vault can be divided in the following phases - hurdle step, contact and takeoff from the springboard, first flight phase, contact and take-off from the table, second flight phase and landing (Fig. 1). All the vaults are categorized into either the continuous rotation or counter-rotation family of vaults. In the continuous rotation vaults, such as the handspring vault, the direction of the body rotation around the somersaulting axis in the second flight phase is the same as that in the first flight phase (Takei, Blucker, Nohara, \& Yamashita, 2000).

After the 2000 Olympic Games, the vaulting apparatus was changed. The traditional horse was replaced by a new vaulting table. This new vaulting table was introduced by the FIG with the aim to improve safety without substantially changing the event (Irwin \& Kerwin, 2009). These changes are producing faster learning 
Fig. 1

Stick figure diagram of handspring and front somersault picked vault phases

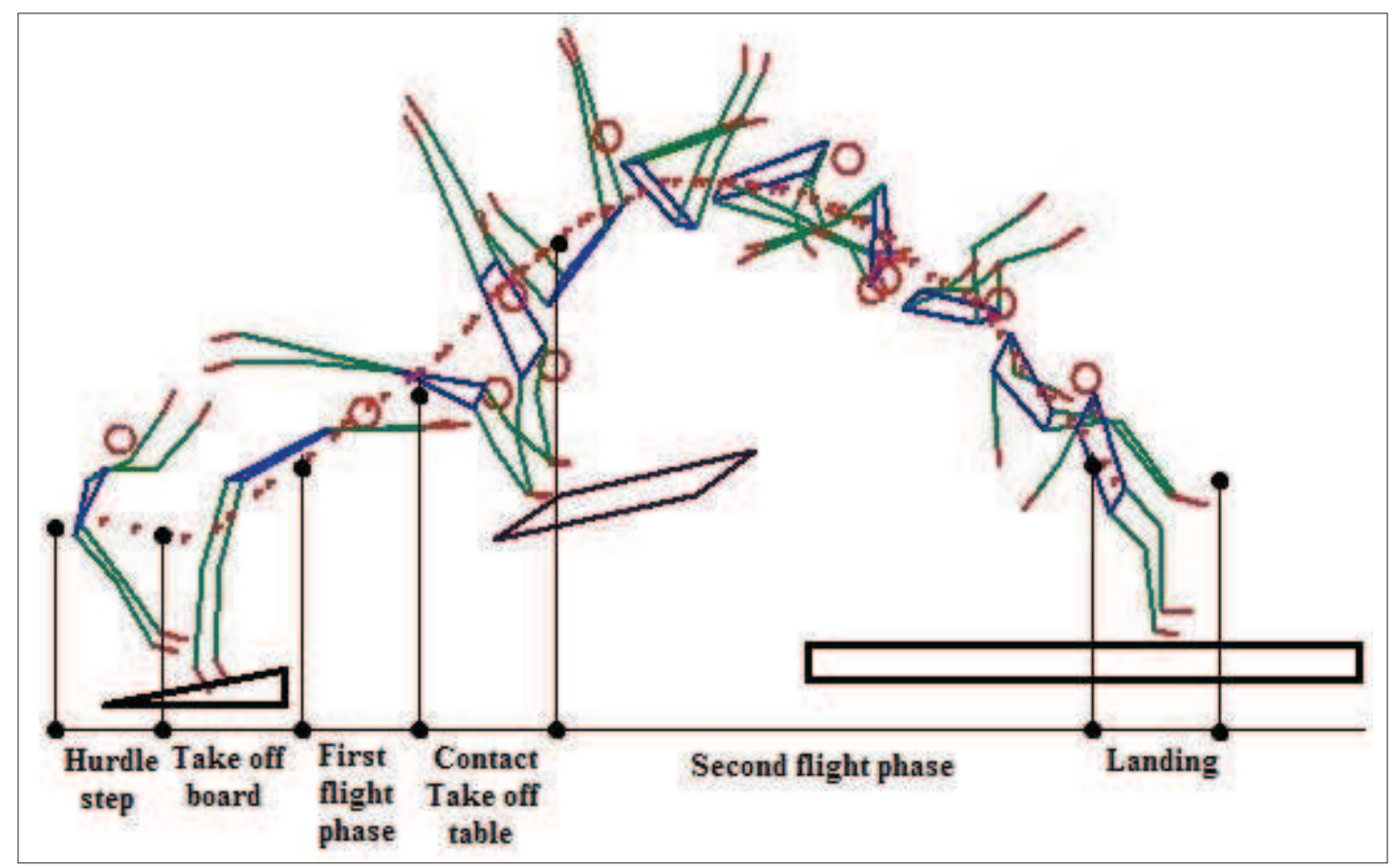

times and more progressive vaults (Rand, 2003). Some of the previous studies discuss the issue of biomechanical factors in the individual vault phases and their effect on the achieved score using deterministic models (Hay \& Reid, 1988). The essence of the theoretical models in artistic gymnastics is to indicate the mutual relations between the resulting score and variables that affect the final score (Takei, 1990, 1992, 1998, 2007; Takei et al., 2000; Prassas, 2002; Penitente, Merni, \& Fantozzi, 2009) or to optimize the course of the movement in the vault (Gervais, 1994). These authors try to find the optimal subset of predictors of the dependent variable from a large set of potential predictors using a model (Hendl, 2009). Krug et al. (1998) states a moderate correlation $(r=0.68 ; p<0.01)$ between the velocity of the run-up and the resulting score. Bradshaw and Sparrow (2001) characterize an explosive run-up by a short duration of the contact with the take-off board that is in a moderate correlation with the duration of the second flight phase $(r=-0.41 ; p<0.05)$ and the resulting score $(r=-0.59 ; p<0.05)$. An increase in the second flight time provides gymnasts with the ability to complete more complex acrobatic movements in the air, thus increasing the degree of difficulty and the potential for a high score (Bradshaw, Hume, Calton, \& Aisbett, 2010). The significant relationships between the vaulting score and specific aspects of the gymnast's vault should compel coaches to monitor these variables as a part of training or routine testing. Evaluating changes in these predictive variables could highlight the gymnast's train- ing progress between competitions (Bradshaw et al., 2010). While biomechanical data of vaulting using the new table (post 2000 Olympic competition) are not available yet, there is a question what the current technique of handspring performed by top-level female gymnasts looks like (Sands, Caine \& Borms, 2003; Bradshaw et al., 2010).

This study focuses on a kinematic analysis of vaults from group 2 which are front handspring and front somersaults, also with rotations around the vertical axis, in the second flight phase (Federation Internationale de Gymnastique, 2009), executed by the artistic female gymnasts who participated in the World Cup competition.

The aim of the study is to determine the biomechanical factors that govern success in the performance of the handspring and front somersault vaults.

\section{METHODS}

All procedures used in this study complied with the guidelines of the University of Ostrava Ethics Committee.

\section{Participants}

Eight top-level female gymnasts $(n=8)$ who participated in the 2010 Ostrava Grand Prix were involved. The age, height and weight of the gymnasts were $19.9 \pm 2.3$ years, $157.5 \pm 4.9 \mathrm{~cm}$ and $50.1 \pm 4.9 \mathrm{~kg}$. All gymnasts performed 
handspring group vaults grader of 4.6 points and higher (Federation Internationale de Gymnastique, 2009). The final score for vaults was $13.35 \pm 0.27$ points.

\section{Data Collection}

For the 3D spatial movement analysis, two digital camcorders (Panasonic NV-MX500EG, Japan) with a frame rate of 50 fields per second were used. The shutter speed was set to $1 / 500 \mathrm{~s}$. The angle between the optical axes of the cameras was near to $90^{\circ}$ (Janura \& Zahálka, 2004). The calibration pole was defined with a calibration bar and was defined by a virtual cube of $7 \times 4 \times 3 \mathrm{~m}$ (Fig. 2).

\section{Data analysis}

The data was digitized by SIMI MOTION software (SIMI Reality Motion Systems, Germany). In each frame, the gymnast's head center and her hand, wrist, elbow, shoulder, hip, knee, ankle and toe on both sides of her body were digitized. A 14-segment model of the human body was created based on 17 body points. For the location of the center of mass (COM), the Gubitz model (Gubitz, 1978) was used. For each vault, approximately 75 fields were digitized. These included every frame from five frames prior to the board touchdown to five after the mat touchdown. The length of the assessed take was 1.5 seconds in all evaluated vaults. The 3D DLT method was used for calculating 3D coordinates of the digitized body parts (Abdel-Aziz \& Karara, 1971). The raw data were smoothed using a low-pass filter with the cut-off frequency of $6 \mathrm{~Hz}$ (Bartlett, 2007). Reconstruction accuracy was 0.013 meters within the 7 meters field of view. A sample vault trial was digitized twice to evaluate digitizer reliability (Kerwin \& Irwin, 2010). Reliability based on repeat digitization of a sam- ple sequence was $<1 \%$ and for temporal and spatial parameters and $<4.5 \%$ for velocity parameters.

\section{Measured biomechanical variables}

A theoretical model of biomechanical variables was used, according to the method of Hay and Reid (1988) and study by Takei et al. (2000), to identify the mechanical variables that determine the linear motions of the gymnast performing handspring and front somersault vaults (Fig. 3).

According to Hay and Reid (1988), the model used in our study consisted of two factors (trajectory of CM in the first flight and trajectory of CM in the second flight) which are identified on the second level and linked to the points awarded by judges on the first level. The trajectory of the center of mass in pre-flight is governed by the resultant velocity at take-off from the board, the relative height of take-off and the time of the first flight (3rd level). The resultant velocity at take-off from the board is the vector sum of the horizontal and vertical velocities at take-off (4th level). Relative height of take-off is determined by the height of the center of mass at the board take-off and the height of the center of mass at the table touchdown (4th level). The time of the first flight is determined by the height of the center of mass and the vertical velocity at take-off from the board and the height of the center of mass at touchdown on the table (4th level).

As shown in Fig. 3, the mechanical variables which govern the trajectory of the center of mass in the second flight phase are similar to those identified on the third and fourth levels of the model for the first flight. More specifically, the vertical velocity at take-off from the table shown on the fourth level is the sum of the vertical velocity at touchdown on the table and the

Fig. 2

Calibration volume, camera set-up and vaulting apparatus

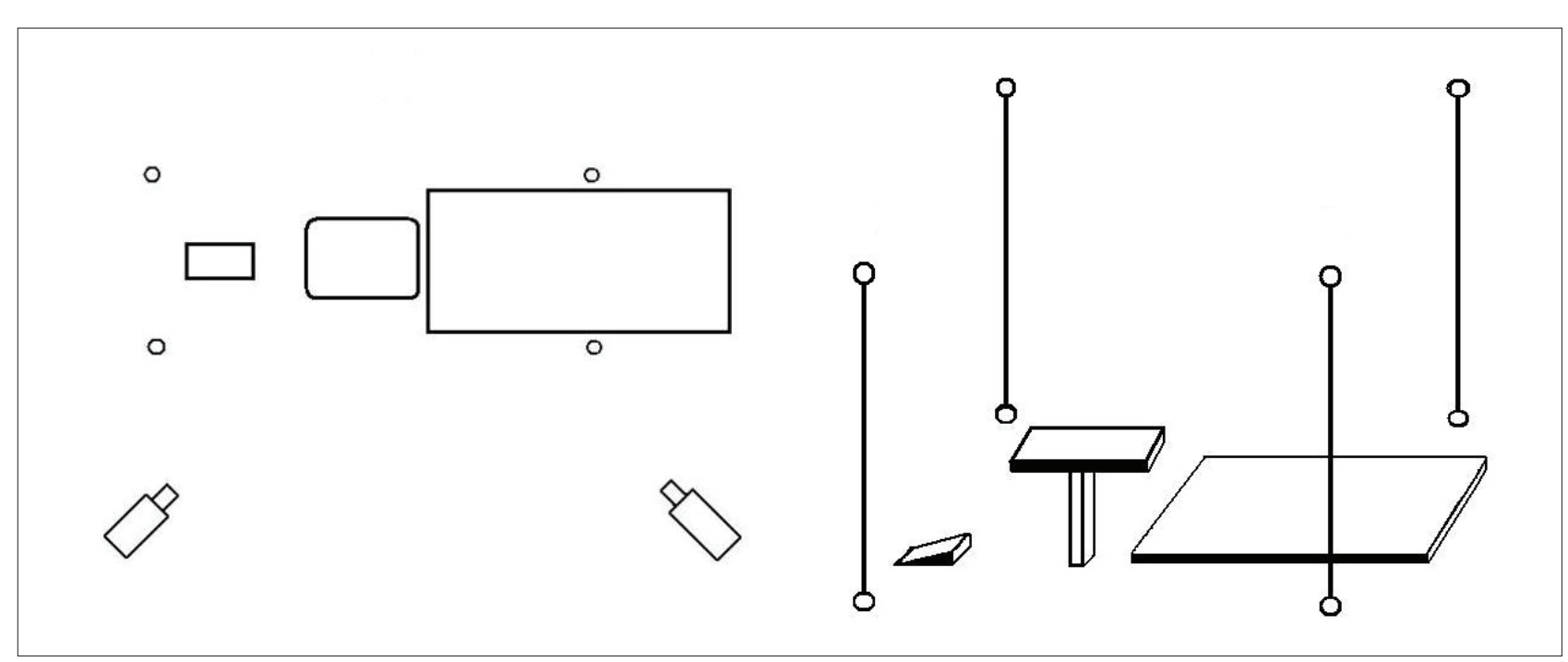


Fig. 3

Model showing factors that determine the linear motions of the handspring vault related to the judges' score

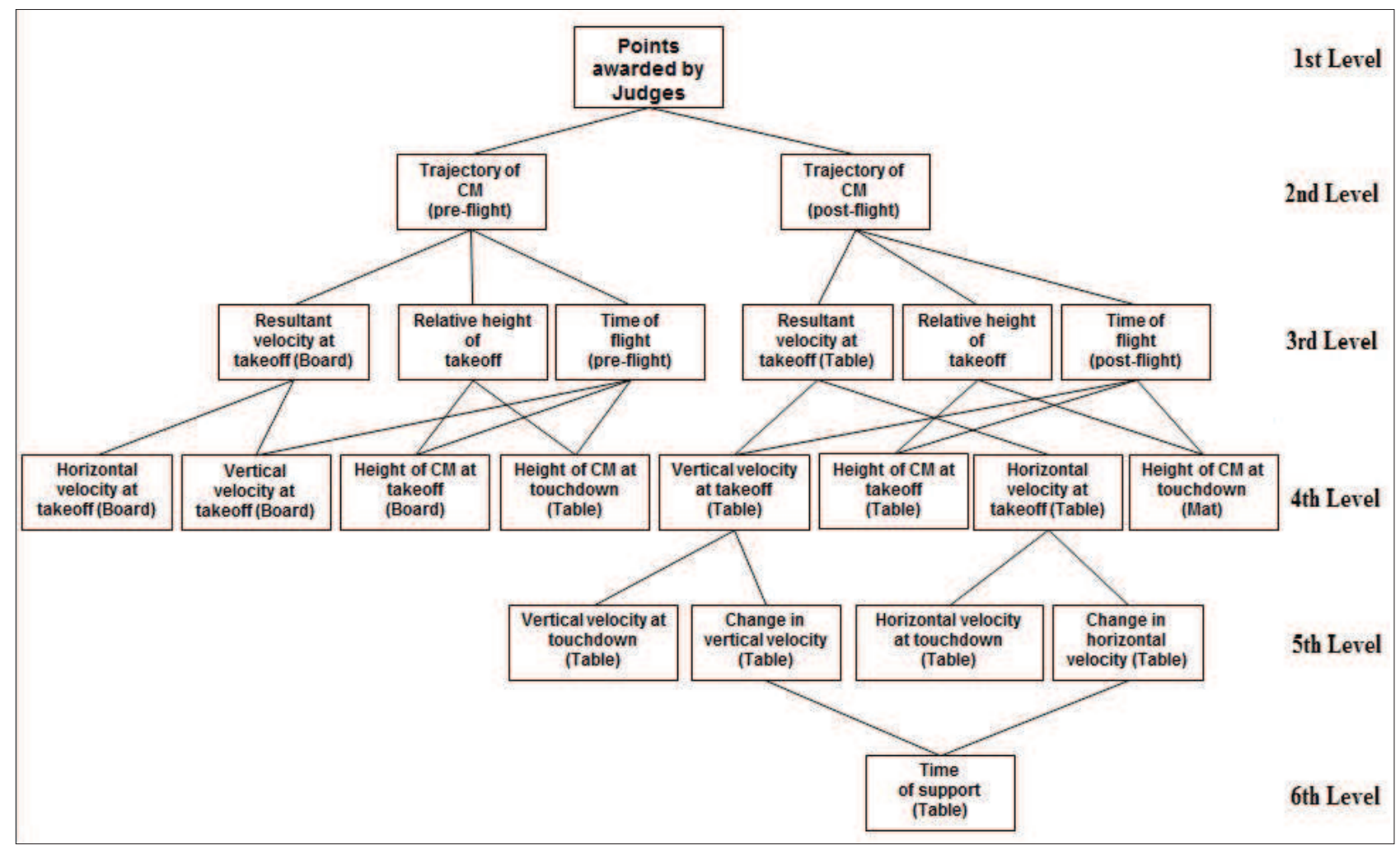

change in the vertical velocity that occurs while on the table (5th level). The horizontal velocity at take-off from the table shown on the fourth level is the sum of the horizontal velocity at touchdown on the table and the change in the horizontal velocity that occurs while on the table (5th level). Changes in the vertical and horizontal velocities are determined by the duration of the table support (6th level).

The variables were also chosen on the basis of previous studies (Nelson, Gross, \& Street, 1985; Takei, 1990, 1998; Takei et al., 2000, Bradshaw et al., 2010) which had solved similar problems.

\section{Statistical analysis}

The mean and standard deviations $(M \pm S D)$ were calculated for each variable. The box-plot was used for outlier identification. To express the statistical relation between the dependent variables and independent variables, the Pearson correlation coefficient was used ( $r$ ). The correlation coefficient was interpreted as $0.1-0.3$ as small, $0.3-0.7$ as moderate and 0.7-1.0 as large (Hendl, 2009). The level of statistical significance was determined to be $p<0.05$. A coefficient of determination $\left(r^{2}\right)$ was calculated for all independent variables - the coefficient is used to express the relation of the explained variability to the total variability of dependent variable Y (Hendl, 2009). IBM SPSS Statistic 19 was used for statistical analysis.

\section{RESULTS}

The descriptive statistics $(M \pm S D)$, correlation coefficients $(r)$ and the coefficient of determination $\left(r^{2}\right)$ for the time, velocity, spatial and angular parameters of the eight vaults executed by the artistic female gymnasts from group vaults 2 (front handspring in the first flight phase and front somersaults, also with rotations around the vertical axis, in the second flight phase) that achieved the highest score are outlined in TABLE 1 and 2 .

\section{DISCUSSION}

The aim of the study was to determine the mechanical variables that govern success in the performance of the handspring and front somersault vaults. In this section we discussed the results of our study relative to the judge's score and to the previous results and conclusions in literature. Based on our results, we also discussed the practical significance for gymnastics training. Takei (2007) states that from the practical point of view, each independent variable that can explain more than $10 \%$ of the total variability of the dependent variable (score in vaulting) is important for further training and practically significant. 
TABLE 1

Descriptive statistics $(M \pm S D)$, correlations $(r)$ and coefficient of determination $\left(r^{2}\right)$ with the judges' score for temporal and linear motion variables in the handspring and front somersault vault

\begin{tabular}{|c|c|c|c|c|c|}
\hline Variable & $\mathrm{M} \pm \mathrm{SD}$ & Min. & Max & $\mathbf{r}$ & $\mathbf{r}^{2}$ \\
\hline \multicolumn{6}{|l|}{ Time (s) } \\
\hline On board & $0.12 \pm 0.01$ & 0.1 & 0.12 & -0.37 & 0.14 \\
\hline First flight & $0.17 \pm 0.03$ & 0.12 & 0.2 & 0.12 & 0.01 \\
\hline On table & $0.156 \pm 0.020$ & 0.12 & 0.18 & -0.49 & 0.24 \\
\hline Second flight & $0.86 \pm 0.07$ & 0.74 & 0.96 & $0.69^{*}$ & 0.48 \\
\hline \multicolumn{6}{|l|}{ Horizontal displacement of $\mathrm{CoG}(\mathrm{m})$} \\
\hline First flight & $0.96 \pm 0.05$ & 0.9 & 1.04 & 0.49 & 0.24 \\
\hline Second flight & $2.94 \pm 0.25$ & 2.7 & 3.37 & 0.54 & 0.29 \\
\hline Official distance of second flight & $2.18 \pm 0.14$ & 2.02 & 2.45 & 0.6 & 0.36 \\
\hline \multicolumn{6}{|l|}{ Height of CoG at critical instants ( $m$ ) } \\
\hline Board take-off & $1.27 \pm 0.04$ & 1.23 & 1.32 & -0.1 & 0.01 \\
\hline Table touchdown & $1.76 \pm 0.05$ & 1.68 & 1.82 & -0.01 & 0.001 \\
\hline Table take-off & $2.16 \pm 0.06$ & 2.09 & 2.25 & $0.86^{*}$ & 0.74 \\
\hline Peak of second flight & $2.49 \pm 0.14$ & 2.35 & 2.66 & $0.83^{*}$ & 0.69 \\
\hline Mat touchdown & $0.91 \pm 0.09$ & 0.8 & 1.05 & 0.41 & 0.17 \\
\hline \multicolumn{6}{|l|}{ Relative height of take off (m) } \\
\hline Board take-off to table touchdown & $0.49 \pm 0.05$ & 0.41 & 0.55 & 0.07 & 0.005 \\
\hline Table take-off to mat touchdown & $1.25 \pm 0.08$ & 1.2 & 1.37 & 0.22 & 0.05 \\
\hline
\end{tabular}

Legend: * $-\mathrm{p}<0,05$, the heights of CoG were measured from the floor

TABLE 2

Descriptive statistics $(M \pm S D)$, correlations $(r)$ and coefficient of determination $\left(r^{2}\right)$ with the judges' score for velocity variables in the handspring and front somersault vault

\begin{tabular}{|l|c|c|c|c|c|}
\hline Variable & M \pm SD & Min & Max & r & $\mathbf{r}^{2}$ \\
\hline Resultant velocity $(\mathbf{m} / \mathbf{s})$ & & & & & \\
\hline Board take-off & $6.04 \pm 0.26$ & 5.85 & 6.54 & 0.57 & 0.32 \\
\hline Table take-off & $3.53 \pm 0.50$ & 2.93 & 4.16 & 0.34 & 0.11 \\
\hline Horizontal velocity $(\mathbf{m} / \mathbf{s})$ & & & & \\
\hline Board take-off & $4.89 \pm 0.33$ & 4.61 & 5.53 & 0.43 & 0.18 \\
\hline Change of table & $-1.79 \pm 0.75$ & -3.22 & -0.96 & $-0.69^{*}$ & 0.48 \\
\hline Table take-off & $3.10 \pm 0.51$ & 2.31 & 3.85 & $0.75^{*}$ & 0.56 \\
\hline Vertical velocity $(\mathbf{m} / \mathbf{s})$ & & & & -0.29 & 0.08 \\
\hline Board take-off & $3.60 \pm 0.18$ & 3.31 & 3.82 & & 0.1 \\
\hline Table touchdown & $1.95 \pm 0.61$ & 1.64 & 3.12 & 0.31 & 0.004 \\
\hline Change of table & $0.72 \pm 0.47$ & 0.12 & 1.26 & 0.06 & 0.35 \\
\hline Table take-off & $2.67 \pm 0.37$ & 2.23 & 3.24 & 0.59 & 0.004 \\
\hline
\end{tabular}

Legend: * $-p<0.05$

\section{Temporal and spatial parameters and judge's score}

A moderate negative correlation in the duration of the take-off board contact $(\mathrm{r}=-0.37)$ and vaulting table $(r=-0.49)$ was found in the temporal parameters. These variables can explain approximately $14 \%$, or $24 \%$, of the total variability of the score. The negative correlation means that the shorter the duration of the take-off phase, the better the execution of the vault is and the better the possibility of a higher score is. This has also been confirmed by Bradshaw and Spar- 
row (2001) who characterize an explosive take-off by the short duration of the contact that is in a moderate correlation with the duration of the second flight phase $(r=-0.41 ; p<0.05)$ and the resulting score $(r=-0.59$; $p<0.05)$. A significant correlation $(r=0.69 ; p<0.05)$ was determined in the duration of the second flight phase and it can explain approximately $48 \%$ of the total variability of the score. A brief contact time on the take-off board and/or vaulting table is likely to translate the gymnast's approach velocity into a longer second flight time (Bradshaw, 2004) or distance provided that the gymnast creates a sufficient impulse through good body mechanics (Bradshaw et al., 2010). Farana and Vaverka (2012) found a very large effect size in duration of contact with the board ( $E S=2)$, duration of the table contact $(E S=3.9)$ and duration of the second flight phase $(E S=3.14)$ when compared handspring vaults with the earlier study by Takei (1990).

A moderate correlation $(r=0.49)$ was determined in the trajectory of the body center of mass during the first flight phase and the official distance of the second flight phase $(r=0.6)$ and can explain approximately $36 \%$ of the total variability of the score. George (2010) states that gymnast should make hand contact with the table as soon as possible during the ascent phase of the first flight trajectory. A negative significant correlation $(\mathrm{r}=-0.83 ; \mathrm{p}<0.05)$ was determined between the official distance of the second flight phase and the duration of the contact with the vaulting table. This means that the shorter the duration of the contact with the vaulting table (a more explosive take-off), the longer the official distance of the second flight phase is. As for the vertical height of the body center of mass, a significant correlation was determined in two variables: the height of the body center of mass during the take-off from the vaulting table $(r=0.86 ; p<0.05)$ and the maximum height of the body center of mass in the second flight phase $(r=0.83 ; p<0.05)$. In the take-off phase, the gymnasts try to complete the vaulting table take-off in the full extent of the movement and to maximize the height of the body center of mass during the take-off and thus the subsequent maximum height of the second flight phase. From the point of practical significance, these two variables are very important for further training as the achieved height of the body center of mass during the take-off can explain approximately $74 \%$ and the maximum height of the body center of mass in the second flight phase approximately $69 \%$ of the total score variability. Also, a significant negative correlation $(r=-0.81$; $\mathrm{p}<0.05$ ) was found between the height of the body center of mass during the vaulting table take-off and the duration of the contact with the vaulting table. Coaches should focus on minimizing the duration of the contact with the vaulting table and on maximizing the height of the body center of mass in the phase of the vaulting table take-off, for instance by suitable exercises from the take-off upper extremities training blocks (Kopřiva \& Pavlík, 1984; Čuk \& Karácsony, 2004). Compared with study of Takei (1990), Farana and Vaverka (2012) found large effect size in maximal height of second flight phase $(\mathrm{ES}=2.62)$.

\section{Velocity parameters and judge's score}

As for the resulting velocity and horizontal component of velocity, a moderate correlation with the resulting score in the phase of the board take-off was found (resulting, $\mathrm{r}=0.57$; horizontal, $\mathrm{r}=0.43$ ). These relations indicate that the higher the velocity of the gymnast during the run-up and take-off, the better the execution of the vault and the chance to get a higher score is. Run-up phases were examined by previous studies. For instance, Krug et al. (1998) reported a moderate correlation $(r=0.68, p<0.01)$ between an average approach velocity and judges' score at the 1997 World Gymnastics Championship. Naundorf, Brehmer, Knoll, Bronst, and Wagner (2008) found out that from 1998 till 2008 the run-up velocity of female gymnasts increased significantly in all vault groups. It could be argued that especially female gymnasts are now able to approach the vault faster due to the much larger "useable" contact area of the new vaulting table (Sands \& McNeal, 2002). The negative significant correlation $(\mathrm{r}=-0.69$; $\mathrm{p}<0.05)$ in the change of the horizontal velocity in the vaulting table take-off phase indicates that the least possible loss of the gained velocity affects the following successful execution of the vault and can explain approximately $48 \%$ of the total score variability. George (2010) states that performer must trade-off a small portion of horizontal velocity to reap tremendous dividends in rotation. The significant correlation $(r=0.75 ; p<0.05)$ of the horizontal component of velocity during the vaulting table take-off and the moderate correlation $(r=0.59)$ of the vertical velocity can explain approximately $56 \%$, or $35 \%$, of the total score variability. Some of the previous studies show that both velocity components are important for the second flight phase. For instance, Prassas (2002) considers the horizontal velocity to be the key parameter for obtaining the required vault length. Farana and Vaverka (2012) found a large effect size in the vertical velocity at take-off from a table $(E S=2.19)$. The vertical velocity is considered to be a decisive factor for obtaining the required height and duration of the second flight phase (Irwin \& Kerwin, 2009).

\section{Limitation of study}

Even though the study has brought some new findings in the field of kinematics of the examined motion, it is necessary to point out some limitations of the study. First of all, it is the extent of the research set that was given by the participants in a Grand Prix competition. 
The selection was based on availability (Hendl, 2009). To understand this issue better, it is thus necessary to work with a wider set of top-level gymnasts under the conditions of a real competition and to broaden the research to vaults from other vault groups. However, small sample sizes are a common feature when undertaking research at elite competition (Manning, Irwin, Gittoes, \& Kerwin, 2011).

\section{CONCLUSIONS}

The study results show that the motions that take place in the phase of the contact with the vaulting table play a key role in the successful execution of the vault and thus in achieving a higher score. It appears that top-level artistic female gymnasts are able to execute the take-off from the vaulting table in a relatively short period of time and with the full extent of the movement (maximization of the height of the body center of mass during the board take-off). The higher the center of mass at take-off from the table, the greater the height, distance, and time of second flight, and therefore the greater the control of body rotation in second flight and the preparation for landing. The vaulting table take-off is executed with high vertical and horizontal velocity that ensures a sufficient height of the vault and landing distance from the vaulting table. Longer time of the second flight allowed gymnasts to complete the rotation motion during the second flight phase and controlled and safe landing.

For practical purposes, the present findings indicate that coaches and gymnasts should focus on achieving:

- Large horizontal and resultant velocity at take-off from the board and a short duration of contact with the board.

- Short duration of contact with the table and maximum height of $\mathrm{CM}$ at the table take-off.

- Small change in the horizontal velocity while on the table and large horizontal and vertical velocity at the table take-off.

- Large amplitude of the second flight phase, which is determined by the second flight duration, maximum height of the second flight and set official distance from the table at the mat touchdown.

\section{ACKNOWLEDGEMENT}

Research was supported by SGS grant from University of Ostrava 2011.

\section{REFERENCES}

Adbel-Aziz, Y. I., \& Karara, H. M. (1971). Direct linear transformation for comparator coordinates in to object space coordinates in close range photogrammetry. In Proceeding of the ASP Symposium in Closerange Photogrammetry (pp. 1-18). Urbana, IL: American Society of Photogrammetry.

Bartlett, R. (2007). Introduction in to biomechanics: Analysing human movement patterns (2nd ed.). Abingdon, UK: Routledge, Taylor and Francis group.

Bradshaw, E. (2004). Target-directed running in gymnastics: A preliminary exploration of vaulting. Sports Biomechanics, 3(1), 125-144.

Bradshaw, E., Hume, P., Calton, M., \& Aisbett, B. (2010). Reliability and variability of day to day vault training measures in artistic gymnastics. Sport Biomechanics, 9(2), 79-97.

Bradshaw, E., \& Sparrow, W. A. (2001). The approach, vaulting performance, and judge's score in women's artistic gymnastics. In J. R. Blackwell \& R. H. Sanders (Eds.), XIX International Symposium of Biomechanics in sport (pp. 311-314). San Francisco: University of San Francisco.

Brüggemann, G. P. (2005). Biomechanical and biological limits in artistic gymnastics. In Q. Wang (Ed.), XXIII International Symposium of Biomechanics in sport (pp. 15-24). Beijing: China Society of Sport Biomechanics.

Čuk, I., \& Karácsony, I. (2004). Vault: Methods, ideas, curiosities, history. Ljubljana: ŠTD Sangvinčki.

Dovalil, J. et al. (2005). Výkon a trénink ve sportu. Praha: Olympia.

Farana, R., \& Vaverka, F. (2012). Současné provedení přemetových přeskoků u vrcholových sportovních gymnastek v podmínkách závodu světového poháru. Česká kinantropologie, 16(1), 69-80.

Federation International de Gymnastique. (2009). Code of points: Women's artistic gymnastics. Lucerne, Switzerland: Rueber.

Gervais, P. (1994). A prediction of an optimal performance of the handspring $1 \frac{1}{2}$ front salto longhorse vault. Journal of Biomechanics, 27, 67-75.

George, G. S. (2010). Championship gymnastics: Biomechanical techniques for shaping winners. California: Wellness Press.

Gubitz, H. (1978). Zur analytischen Bestimmung der Lage des Koerperschwerpunktes. In International Symposium (pp. 171-180). Berlin: Germany.

Hay, G. J., \& Reid, G. J. (1988). Anatomy, mechanics and human motion (2nd ed.). Upper Saddle River: Prentice Hall. 
Hendl, J. (2009). Přehled statistických metod: Analýza a metaanalýza dat (3rd ed.). Praha: Portál.

Irwin, G., \& Kerwin, D. (2009). The influence of the vaulting table on the handspring front somersault. Sports Biomechanics, 8(2), 114-128.

Janura, M., \& Zahálka, F. (2004). Kinematická analýza pohybu člověka. Olomouc: Univerzita Palackého v Olomouci.

Kopřiva, Z., \& Pavlík, J. (1984). Technická př́prava v základní a specializované etapě tréninku žáků sportovní gymnastiky [Metodický dopis]. Praha: ÚV ČSTV.

Krug, J., Knoll, K., Köthe, T., \& Zocher, D. H. (1998). Running approach velocity and energy transformation in difficult vaults in gymnastics. In H. J. Riehle \& M. M. Vieten (Eds.), XVI International Symposium of biomechanics in sports (pp. 160-163). Konstanz: Germany.

Manning, M. L., Irwin, G., Gittoes, M. J. R, \& Kerwin, D. G. (2011). Influence of longswing technique on the kinematics and key release parameters of the straddle Tkachev on uneven bars. Sports Biomechanics, 10(3), 161-173.

McGinnis, P. M. (2005). Biomechanics of sport and exercise (2nd ed.). Champaign, IL: Human Kinetics.

Nelson, R. C., Gross, T. S., \& Street, G. M. (1985). Vaults performed by female Olympic gymnasts: A biomechanical profile. International Journal of Sport Biomechanics, 1, 111-121.

Naundorf, F., Brehmer, S., Knoll, K., Bronst, A., \& Wagner, R. (2008). Development of velocity for vault runs in artistic gymnastics for last decade. In Y. H. Kwon, J. Shim, J. K. Shim, \& I. S. Shin (Eds.), XXVI International Symposium of biomechanics in sports (pp. 481-484). Seoul: Korea.

Penitente, G., Merni, F., \& Fantozzi, S. (2009). Onboard anf pre-flight mechanical model of Yurchenko one twist on vault: Implications for performance. In A. J. Harrison, R. Anderson, \& I. Kenny (Eds.), XXVII International Symposium of biomechanics in sports (pp. 636-639). Limerick: Ireland.

Prassas, S. (2002). Vaulting mechanics. Retrieved 11. 11. 2011 from the World Wide Web: http://www.coachesinfo.com/index.php?option=com_content\&view=arti cle\&id=180:gymnastics-valutingmechanics \&catid=61: gymnastics-general-articles\&Itemid $=105$

Prassas, S., Kwon, Y. H., \& Sands, W. A. (2006). Biomechanical research in artistic gymnastics: A review. Sports Biomechanics, 5(2), 261-291.

Rand, T. (2003). New vaulting table. Technique, 23(1), 9-10.

Sands, W. A., Caine, D. J., \& Borms, J. (2003). Scientific aspects of women's gymnastics. Basel: S. Karger Publisher.
Sands, W. A., \&, McNeal, J. R. (2002). Some guidelines on the transition from the old horse to the new table. Technique, 22, 22-25.

Takei, Y. (1990). Technique used by elite women gymnasts performing a handspring vault at the 1987 Pan American Games. International Journal of Sport Biomechanics, 6, 29-55.

Takei, Y. (1992). Blocking and post flight technique of male gymnasts performing the compulsory vault at the 1988 Olympics. International Journal of Applied Biomechanics, 7, 87-110.

Takei, Y. (1998). Three-dimensional analysis of handspring with full turn vault: Deterministic model, coaches' beliefs, and judges' scores. Journal of Applied Biomechanics, 14, 190-210.

Takei, Y. (2007). The roche vault performed by elite gymnasts: Somersaulting technique, deterministic model, and judges' scores. Journal of Applied Biomechanics, 23, 1-11.

Takei, Y., Blucker, E., Nohara, H., \& Yamashita, N. (2000). The Hecht vault performed at the 1995 World Gymnastics Championships: Deterministic model and judges' scores. Journal of Sports Sciences, 18, 849-863.

\section{VLIV BIOMECHANICKÝCH PROMĚNNÝCH NA HODNOCENÍ PŘESKOKŮ VRCHOLOVÝCH SPORTOVNÍCH GYMNASTEK PŘI ZÁVODĔ SVĚTOVÉHO POHÁRU}

(Souhrn anglického textu)

VÝCHODISKA: Sportovní výkon v přeskoku trvá krátký čas a je ovlivněn množstvím biomechanických proměnných. Po olympijských hrách v roce 2000 bylo tradiční přeskokové nářadí nahrazeno moderním přeskokovým stolem. V současné době nejsou známy komplexní biomechanická data o přeskocích při použití nového přeskokového stolu a je otázkou, jaké je současné provedení přemetových přeskoků u vrcholových sportovních gymnastek.

CÍL: Cílem studie je určit, které biomechanické faktory se podílejí na úspěšném provedení přemetových skoků.

METODA: Výzkumu se účastnilo osm vrcholových sportovních gymnastek. Pro 3D prostorovou analýzu byly použity dva digitální kamkordéry se snímkovací normou 50 půlsnímků/s. Data byla digitalizována pomocí softwaru Simi motion. Metoda podle Haye a Reida (1988) byla použita pro identifikaci biomechanických proměnných, které ovlivňují průběh přemetových skoků. Pro posouzení závislosti mezi biomechanickými proměnnými a bodovým hodnocením byla použita korelační analýza. Hladina statistické významnosti byla nastavena na hladinu $\mathrm{p}<0.05$. 
VÝSLEDKY: Z 23 vyšetřovaných proměnných byly u pěti zjištěny signifikantní korelace $\mathrm{s}$ bodovým hodnocením. Signifikantní korelace byla zjištěna u vertikální výšky těžiště těla při odrazu z přeskokového stolu $(\mathrm{r}=0.86)$, maximální výšky těžiště těla ve druhé letové fázi $(r=0.83)$, změně horizontální rychlosti ve fázi odrazu z přeskokového stolu $(\mathrm{r}=-0.69)$, u horizontální složky rychlosti při odrazu $\mathrm{z}$ přeskokového nářadí $(\mathrm{r}=0.75)$ a doby trvání druhé letové fáze $(\mathrm{r}=0.69)$.

ZÁVĚR: Fáze odrazu z přeskokového stolu je klíčovou fází skoku. Vrcholové sportovní gymnastky dokážou provést odraz z přeskokového stolu $\mathrm{v}$ relativně krátkém časovém úseku a v plném rozsahu pohybu (maximalizace výšky těžišstě těla při odrazu z můstku). Odraz $\mathrm{z}$ přeskokového stolu je proveden $\mathrm{s}$ vysokou vertikální a horizontální rychlostí, čímž je zajištěna dostatečná výška skoku a vzdálenost doskoku od přeskokového nářadí. Sportovní gymnastky tak mají dostatek času pro dokončení rotačního pohybu a kontrolovaný a bezpečný doskok.

Kličová slova: sportovní biomechanika, kinematická analýza, technika, korelační analýza, bodové hodnocení.

\section{Mgr. Roman Farana}

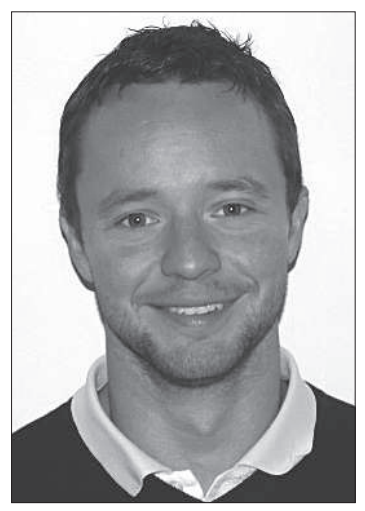

University of Ostrava

Pedagogical Faculty

Human Motion Diagnostic

Centre

Varenská 40a

70103 Moravská Ostrava

Czech Republic

Education and previous work experience

2004-2008 - University of Ostrava, Pedagogical Faculty - Master degree.

Since 2008 - lector of gymnastics, Department of Physical Education, Pedagogical Faculty, University of Ostrava.

Since 2009 - Ph.D. study program, Faculty of Physical Culture, Palacký University, Olomouc.

1st class gymnastics coach.

First-line publications

Farana, R., \& Vaverka, F. (2011). Biomechanická analýza přeskoků ve sportovní gymnastice z pohledu kinematiky - přehledová studie. Česká kinantropologie, 15(1), 35-47.

Farana, R., \& Vaverka, F. (2012). Současné provedení přemetových přeskoků u vrcholových sportovních gymnastek v podmínkách závodu světového poháru. Česká kinantropologie, 16(1), 69-80.

Farana, R., Vaverka, F., \& Hendl, J. (2012). Model biomechanických proměnných $\mathrm{v}$ biomechanice sportu a tělesných cvičení. Česká kinantropologie, 16(1), 36-47.

Farana, R., Uchytil, J., Jandačka, D., Zahradník, D., \& Vaverka, F. (2012). Comparison of the key kinematic parameters of difficult handpsring and tsukahara vaults performed by elite male gymnasts. In E. Bradshaw, A. Burnett, \& P. Hume (Eds.), XXX International Symposium of Biomechanics in Sports (pp. 280-283). Melbourne: Australia.

Farana, R. (2011). Základní gymnastika. Ostrava: Ostravská univerzita v Ostravě. 